\title{
CONCURRENT ESTIMATION OF SOFOSBUVIR AND VELPATASVIR IN RAW AND TABLETS USING STABILITY INDICATING RP-HPLC METHOD
}

\author{
J. Saroja ${ }^{1}$, P.V. Anantha Lakshmi, ${ }^{2,}$, Y. Rammohan', D. Divya1, \\ and P. Santhosh Kumar ${ }^{1}$ \\ ${ }^{1}$ Department of Chemistry, CMR College of Engineering \& Technology, \\ Hyderabad - 501401, India. \\ ${ }^{2}$ Department of Chemistry, University College of Technology, Osmania University, \\ Hyderabad - 500007, India. \\ *E-mail: pvanantha.ou@ gmail.com
}

\begin{abstract}
A stability indicating RP-HPLC method is developed and evaluated to quantify sofosbuvir and velpatasvir in raw and tablets forms. The method involves separation and analysis of sofosbuvir, velpatasvir and their stress degradants using Spursil C18 $(250 \times 4.5 \mathrm{~mm}$ and i.d., $5 \mu \mathrm{m}$ particle size $)$ analytical column with a mixture of potassium dihydrogen phosphate $(0.1 \mathrm{M})$ and methanol $(\mathrm{pH} 4.5,60: 40 \mathrm{v} / \mathrm{v})$ as the mobile phase. The analysis was done using a photodiode array detector at $240 \mathrm{~nm}$. Calibration curves showed linearity in concentration range 10-30 (velpatasvir) and $40-120 \mu \mathrm{g} / \mathrm{mL}$ (sofosbuvir). Good linearity $\left(R^{2} \geq 0.9998\right)$, good precision (RSD $\leq 0.138 \%, \mathrm{n}=5$ ) and good accuracy $(\%$ recovery $100 \%)$ for velpatasvir and sofosbuvir were achieved. Stress degradation studies were performed on powdered tablet sample in athe cidic, basic, oxidative, thermal and photolytic atmosphere. The method showed no interference from the degradation products formed by applied stress conditions. Application of the proposed method to the commercially available tablets was carried out successfully. The performance of the proposed method was compared with those from previously published HPLC methods and they were satisfactory.

Key words: hepatitis $C$ virus, sofosbuvir, velpatasvir, stability indicating, analysis, tablets
\end{abstract}

(C) RASĀYAN. All rights reserved

\section{INTRODUCTION}

Hepatitis $\mathrm{C}$ is a chronic infection by hepatitis $\mathrm{C}$ virus with nearly $130-150$ million of the population infected globally ${ }^{1,2}$. Hepatitis $C$ virus is a single-stranded ribonucleic acid virus belonging to the family Flaviviridae. The most important objective of hepatitis $\mathrm{C}$ virus therapy is to obtain a sustained virological response, resulting in complete eradication of Hepatitis C viral RNA levels, within 24 weeks following completion of treatment ${ }^{3}$. A tablet dosage combination of velpatasvir and sofosbuvir was approved in June 2016 by the United States Food and Drug Administration in treating hepatitis C virus-infected patients ${ }^{4,5}$.

Sofosbuvir (a phosphoramidate prodrug) undergoes extensive intracellular metabolism to form deoxy- $\alpha$ fluoro- $\beta$-C-methyluridine triphosphate (active antiviral agent). This active antiviral agent is a defective substrate for non-structural protein $5 \mathrm{~B}$ which is required for transcription of viral $\mathrm{RNA}^{6}$. Velpatasvir inhibits hepatitis $\mathrm{C}$ virus non-structural protein $5 \mathrm{~A}$ and possesses potent antiviral activity against all genotypes. Non-structural protein $5 \mathrm{~A}$ is required for viral replication ${ }^{7}$. The chemical structures of the sofosbuvir and velpatasvir are given in Fig. -1 and -2 .

The sofosbuvir and velpatasvir combination is not yet official in pharmacopoeia. Two articles on the concurrent estimation of sofosbuvir \& velpatasvir in tablet dosage were recently reported by Sarath \& Rao and Uppalapati \& Parimi ${ }^{8,9}$. 
In Sarath \& Rao method, separation and analysis were done using Discovery® C18 column with orthophosphoric acid plus acetonitrile $(60: 40 \mathrm{v} / \mathrm{v})$ at a flow rate of $1.0 \mathrm{~mL} / \mathrm{min}^{8}$ as mobile phase. UV detection was performed at $240 \mathrm{~nm}$. Uppalapati \& Parimi achieved separation using mobile phase having $0.1 \%$ trifluoro acetic acid: methanol $(42: 58 \mathrm{vol} / \mathrm{vol})$ on an XTerra RP18 column ${ }^{9} .1 .0 \mathrm{~mL} / \mathrm{min}$ is the flow rate and $269 \mathrm{~nm}$ is used for detecting analytes.

Present work describes validated rapid, precise, accurate stability indicating RP-HPLC method in the quantitation of sofosbuvir \& velpatasvir combination in raw and tablets.<smiles>CC(C)OC(=O)[C@H](C)NOP(=O)(OCC1CC2OC1C2(F)F)Oc1ccccc1</smiles>

Isopropy|(2S)-2-[[[(2R,3R,4R,5R)-5-(2,4-dioxopyrimidin-1-yl)-4fluoro-3-hydroxy-4-methyl-tetrahydrofuran-2-yl]methoxy-pheno xy-phosphoryl]amino]propanoate

Fig. -1: Chemical Name and Structure of Sofosbuvir<smiles></smiles>

Methyl\{(2S)-1-[(2S,5S)-2-(9-\{2-[(2S,4S)-1-\{(2R)-2-[(methoxycarbonyl)amino]2-phenylacetyl\}-4-(methoxymethyl)-2-pyrrolidinyl]-1 H-imidazol-4-yl\}-1,11-dihy droisochromeno[4', 3':6,7]naphtho[1,2-d]imidazol-2-yl)-5-methyl-1-pyrrolidinyl] -3-methyl-1-oxo-2-butanyl\}carbamate

Fig.-2: Chemical Name and Structure of Velpatasvir

\section{Instrumentation}

\section{EXPERIMENTAL}

HPLC system (Waters) with binary HPLC pump (model number 2695), PDA detector (model number 2998) and degasser with $10 \mu \mathrm{L}$ injection loop were used. The chromatographic data was processed by Waters Empower2 software. Electronic balance ELB 300 and Digisun pH meter were used.

\section{Materials}

Lara Drugs Private Limited (Hyderabad, Telangana, India) was kind enough in providing sofosbuvir and velpatasvir reference substances. Sovihep V tablets having $400 \mathrm{mg}$ of sofosbuvir \& $100 \mathrm{mg}$ of velpatasvir (Zydus Heptiza, Ahmedabad, India) were obtained from commercial sources. Methanol of HPLC grade was acquired from Merck Pvt Ltd. (Mumbai, Maharashtra, India). Potassium dihydrogen phosphate, orthophosphoric acid, hydrochloric acid, hydrogen peroxide and sodium hydroxide of analytical reagent 
grade were acquired from Sd Fine Chemicals Ltd. (Mumbai, Maharashtra, India). Water purified via Milli-Q system was used in the study.

\section{Chromatographic Conditions}

The chromatographic separation and analysis of selected drug combination were worked out on a Spursil C18 $(250 \times 4.5 \mathrm{~mm}$, i.d., $5 \mu \mathrm{m}$ particle size $)$. The mobile phase used is a mixture of $10^{-1} \mathrm{M}$ potassium dihydrogen phosphate \& and methanol $(\mathrm{pH} \mathrm{4.5,60:40} \mathrm{v/v).} 1 \mathrm{~mL} / \mathrm{min}$ is the flow rate. Mobile phase filtration using $0.45 \mu \mathrm{m}$ membrane filter was done and $10 \mathrm{~min}$ sonication was performed. The column temperature is $25 \pm 2{ }^{\circ} \mathrm{C}$ while analyzing. The analyte elution was monitored using a photodiode array detector set at $240 \mathrm{~nm} .10 \mu \mathrm{L}$ is the injection volume.

\section{Solutions of Stock Standard and Tablet Sample}

The stock solution was prepared by weighing $400 \mathrm{mg}$ sofosbuvir \& $100 \mathrm{mg}$ velpatasvir, and dissolved in $30 \mathrm{~mL}$ of mobile phase in a volumetric flask having $100 \mathrm{ml}$ capacity. A concentration of $4000 \mu \mathrm{g} / \mathrm{mL}$ and $1000 \mu \mathrm{g} / \mathrm{mL}$ of sofosbuvir and velpatasvir was achieved by the mobile phase to the final volume of the volumetric flask. The prepared solution was further diluted using mobile phase to attain working standards having concentration $10,15,20,25 \& 30 \mu \mathrm{g}$ per $\mathrm{mL}$ for velpatasvir and 40,60, 80, $100 \& 120$ $\mu \mathrm{g}$ per $\mathrm{mL}$ for sofosbuvir.

Ten tablets of Sovihep V (400 mg sofosbuvir and $100 \mathrm{mg}$ velpatasvir/tablet) were powdered. Tablet powder equal to $400 \mathrm{mg}$ sofosbuvir \& $100 \mathrm{mg}$ velpatasvir is accurately weighed into a volumetric flask having $100 \mathrm{ml}$ capacity and mixed with 30 milli liters mobile phase. Sonication of solution performed for 20 minutes and filled by mobile phase for obtaining a final concentration of $1000 \mu \mathrm{g} / \mathrm{mL}$ velpatasvir and $4000 \mu \mathrm{g} / \mathrm{mL}$ sofosbuvir. Filtration of the solution was through $0.45 \mu \mathrm{m}$ membrane. For analyzing the analytes, the above-prepared tablet sample solution was diluted further to reach a concentration of 80 $\mu \mathrm{g} / \mathrm{mL}$ and $20 \mu \mathrm{g} / \mathrm{mL}$ sofosbuvir and velpatasvir, respectively with the mobile phase.

\section{Degradation Study}

In this study, acidic, basic, oxidative, thermal, and photolytic degradation of tablet solution $(20 \mu \mathrm{g} / \mathrm{mL}$ velpatasvir \& $80 \mu \mathrm{g} / \mathrm{mL}$ sofosbuvir) were studied ${ }^{10}$. Acid and base degradation studies were performed using tablet powder equivalent to $400 \mathrm{mg}$ sofosbuvir and $100 \mathrm{mg}$ velpatasvir in $\mathrm{HCl}(0.1 \mathrm{~N}, 10 \mathrm{~mL})$ and $\mathrm{NaOH}(0.1 \mathrm{~N}, 10 \mathrm{~mL})$, respectively and sonicated at room temperature for $30 \mathrm{~min}$. For oxidative degradation, the same concentration of tablet sample was used in $30 \%$ hydrogen peroxide $(10 \mathrm{~mL})$ followed by sonication at room temperature for $30 \mathrm{~min}$. Thermal and photolytic degradation studies were performed on tablet powder (equivalent to $400 \mathrm{mg}$ sofosbuvir and $100 \mathrm{mg}$ velpatasvir). The tablet powder was exposed to $105^{\circ} \mathrm{C}$ for $30 \mathrm{~min}$ in oven (thermal degradation) or to sun light for 1 day (photolytic degradation). After degrading, tablet solution was prepared as explained in "stock standard and tablet sample solutions" section.

After the application of stress on the tablet sample, the stressed samples dilution was done by mobile phase to a concentration of $20 \mu \mathrm{g}$ per $\mathrm{mL}$ velpatasvir \& $80 \mu \mathrm{g}$ per $\mathrm{mL}$ sofosbuvir for analysis. The degraded samples are filtered and then injected into the HPLC system. Calculation of peak area for velpatasvir \& sofosbuvir were noted from the respective chromatogram. Working standard solution at the same concentration level was used to calculate the percentage of the drug remained in each degradation condition. The peak purity of velpatasvir and sofosbuvir was also determined in all the degradation conditions.

\section{Method Optimization}

\section{RESULTS AND DISCUSSION}

Parameters of chromatography parameters - a time of retention, peak tailing, theoretical plates count, and resolution were determined to optimize the method. For that, trials are carried out - different mobile phase ratios and different stationary phase types, with temperature difference, values of $\mathrm{pH}$ and flow rate. On this basis method is employed to separate velpatasvir and sofosbuvir from themselves and also from stress degradants, Spursil C18 $(250 \times 4.6 \mathrm{~mm}, 5 \mu \mathrm{m})$ column having temperature $25 \pm 2{ }^{\circ} \mathrm{C}$ was selected which gave good symmetric and sharp peaks. Based on less analysis time, peak response, peak symmetry and 
column efficiency, a mixture of methanol and $10^{-1} \mathrm{M}$ potassium dihydrogen orthophosphate and methanol $(40: 60 \mathrm{v} / \mathrm{v})$ was selected as mobile phase with adjustment $\mathrm{pH}$ to 4.5 units and 1.0 millilitre/minute flow rate, using photodiode array detector, a wavelength of $240 \mathrm{~nm}$ was selected as detection wavelength. The chromatographic parameters optimized exhibit a good peak shape, resolution and a good number of theoretical plates. The typical chromatogram of velpatasvir and sofosbuvir by the developed method is presented in Fig. -3.

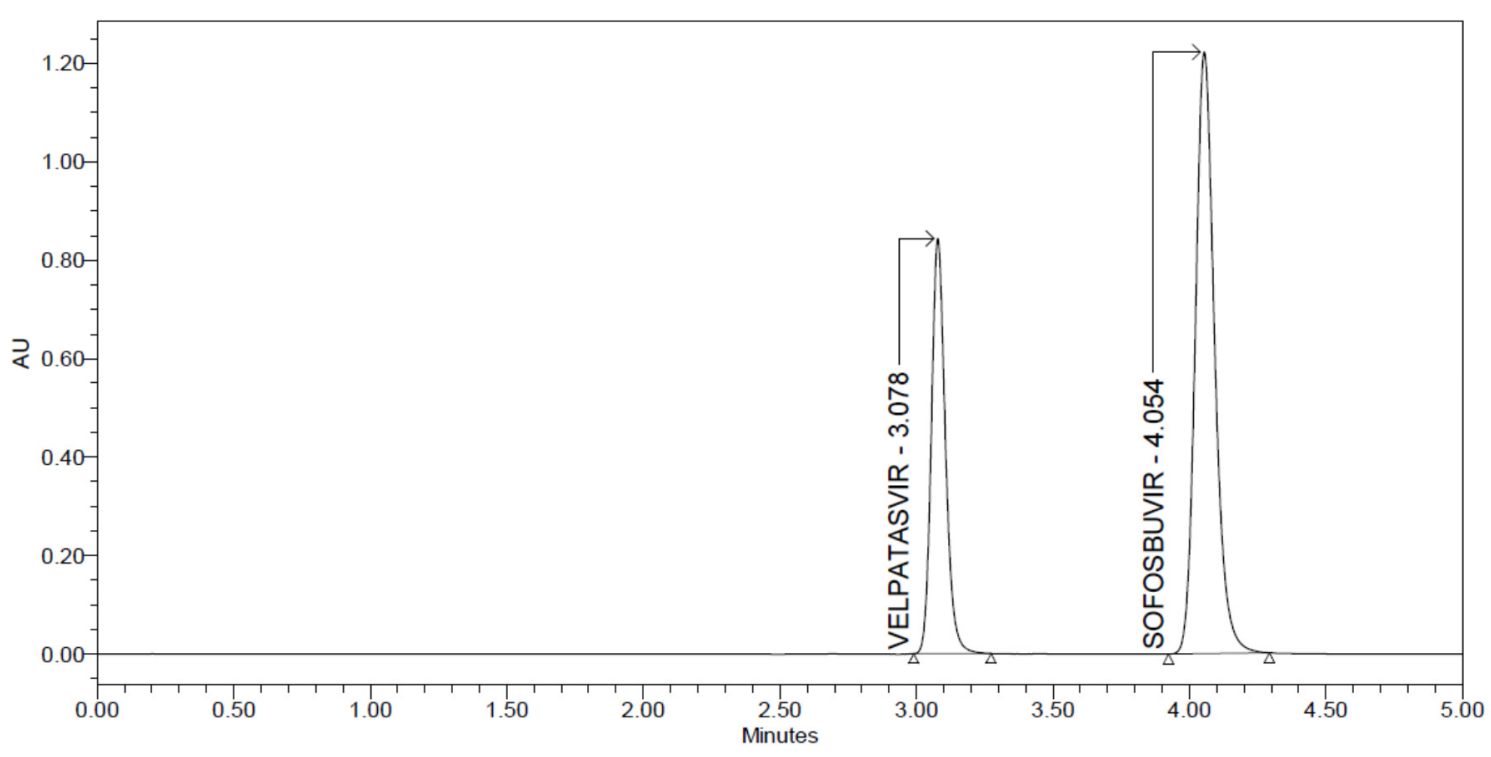

Fig.-2: Typical Chromatogram of Velpatasvir and Sofosbuvir by the Developed Method

\section{Method Validation}

Validation was performed by referring ICH guidelines ${ }^{11}$. HPLC Suitability, linearity, selectivity, accuracy, sensitivity, precision, specificity and robustness were determined.

\section{System Suitability Study}

System suitability established by five consecutive injections with the same working standard solutions. Parameters considered were: USP plate count, USP tailing, USP resolution, peak areas' and retention times' relative standard deviation of velpatasvir and sofosbuvir. The values for the system suitability parameters of the method, as presented in Table- 1, are within acceptance limits.

Table-1: System suitability parameters for velpatasvir and sofosbuvir

\begin{tabular}{c|c|c|c|c|c}
\hline Sample Name. & $\begin{array}{c}\text { Retention } \\
\text { time }\end{array}$ & $\begin{array}{c}\text { Peak } \\
\text { Area }\end{array}$ & $\begin{array}{c}\text { Plate } \\
\text { count }\end{array}$ & $\begin{array}{c}\text { Tailing } \\
\text { factor }\end{array}$ & Resolution \\
\hline \multicolumn{7}{c}{ Velpatasvir $(20 \mu \mathrm{g} / \mathrm{mL})$} \\
\hline $\mathrm{A}$ & 3.089 & 2443324 & 17609 & 1.16 & - \\
\hline $\mathrm{B}$ & 3.088 & 2446997 & 17643 & 1.13 & - \\
\hline $\mathrm{C}$ & 3.090 & 2431515 & 17668 & 1.13 & - \\
\hline $\mathrm{D}$ & 3.088 & 2446115 & 17338 & 1.13 & - \\
\hline E & 3.090 & 2426416 & 17340 & 1.14 & - \\
\hline RSDerage & 3.089 & 2438873 & 17520 & 1.138 & - \\
\hline $\begin{array}{l}\text { Recommended } \\
\text { limit }\end{array}$ & 0.032 & 0.382 & 0.949 & 1.146 & - \\
\hline \multicolumn{7}{c|}{ RSD $\leq 2$} & RSD $\leq 2$ & $>2000$ & $\leq 2$ & - \\
\hline \multicolumn{7}{c|}{ A } & 4.061 & 5979429 & 16412 & 1.2 & 8.66 \\
\hline
\end{tabular}


RASĀYAN J. Chem.

Vol. 11 | No. 3 |1058 - 1066 | July - September | 2018

\begin{tabular}{l|c|c|c|c|c}
\hline \multicolumn{1}{c|}{ C } & 4.061 & 5962666 & 16396 & 1.2 & 8.59 \\
\hline \multicolumn{1}{c|}{ D } & 4.061 & 5930444 & 16458 & 1.2 & 8.59 \\
\hline \multicolumn{1}{c|}{ E } & 4.062 & 5947656 & 16444 & 1.21 & 8.58 \\
\hline Average & 4.061 & 5952821 & 16415 & 1.202 & 8.602 \\
\hline RSD & 0.027 & 0.316 & 0.231 & 0.372 & 0.380 \\
\hline $\begin{array}{l}\text { Recommended } \\
\text { limit }\end{array}$ & RSD $\leq 2$ & RSD $\leq 2$ & $>2000$ & $\leq 2$ & $>1.5$ \\
\hline
\end{tabular}

\section{Selectivity}

The selectivity of the optimized HPLC method was examined with standard working solution of velpatasvir $(20 \mu \mathrm{g}$ per $\mathrm{mL}) \&$ sofosbuvir $(80 \mu \mathrm{g}$ per $\mathrm{mL})$ relative to the placebo blank, blank mobile phase and tablet sample solution (velpatasvir $-21 \mu \mathrm{g} / \mathrm{mL}$ and sofosbuvir $-80 \mu \mathrm{g} / \mathrm{mL}$ ) (Fig. -4). No interference was observed by coelution of the excipients in placebo blank, components of the mobile phase at the same retention time of velpatasvir and sofosbuvir at $240 \mathrm{~nm}$, demonstrating the selectivity of this method. The time of velpatasvir \& sofosbuvir retention in working solution and tablet solution are alike.
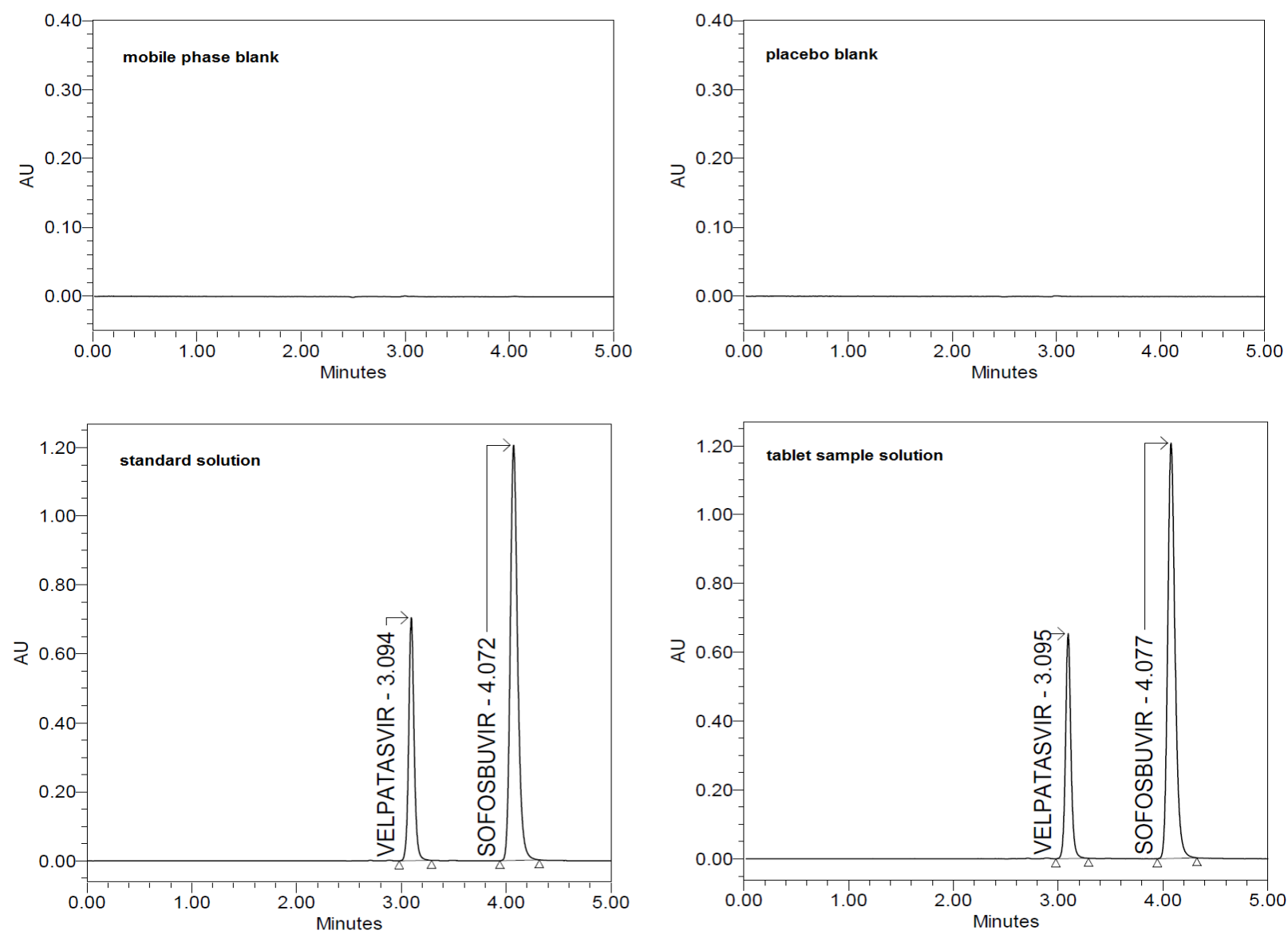

Fig.-4: Chromatograms of Selectivity Study

\section{Linearity and Sensitivity}

Linearity was done by preparing standard solutions of velpatasvir and sofosbuvir at five concentration levels. The linearity of detector response for velpatasvir and sofosbuvir was verified by prepared solutions in concentration range 10-30 and 40-120 $\mu \mathrm{g}$ per $\mathrm{mL}$, respectively. Peak area of each sample against respective concentration of analytes was found to be linear. Correlation coefficient of velpatasvir \& sofosbuvir are $0.9998 \& 0.9999$. Linearity results were presented in Table-2. 
RASĀYAN J. Chem.

Vol. 11 | No. 3 |1058 - 1066 | July - September | 2018

This method's sensitivity was represented as limits of quantification (LOQ) and detection (LOD). Determining detection and quantitation limits is based on the signal-to-noise ratio with 3:1 \& 10:1. Determined LOD values and LOQ values for velpatasvir and sofosbuvir were shown in Table-2.

Table-2: Regression Analysis and Sensitivity of Velpatasvir and Sofosbuvir

\begin{tabular}{l|c|c}
\multicolumn{1}{c|}{ Parameter } & Velpatasvir & Sofosbuvir \\
\hline Linearity $(\mu \mathrm{g} / \mathrm{mL})$ & $10-30$ & $40-120$ \\
\hline $\begin{array}{l}\text { Equation of regression } \\
(\mathrm{A}=\mathrm{SC}+\mathrm{I})\end{array}$ & $\mathrm{y}=12198 \mathrm{x}-2111$ & $\mathrm{y}=74403 \mathrm{x}+1087$ \\
\hline Slope $(\mathrm{S})$ & 12198 & 74403 \\
\hline Intercept on Y-axis $(\mathrm{I})$ & -2111 & 1087 \\
\hline Regression coefficient $\left(\mathrm{R}^{2}\right)$ & 0.9998 & 0.9999 \\
\hline LOD $(\mu \mathrm{g} / \mathrm{mL})$ & 0.186 & 0.428 \\
\hline LOQ $(\mu \mathrm{g} / \mathrm{mL})$ & 0.620 & 1.609 \\
\hline
\end{tabular}

$\mathrm{A}=$ Peak area of analyte; $\mathrm{I}=$ analytes' concentration $(\mu \mathrm{g} / \mathrm{mL})$

\section{Precision and Accuracy}

For precision studies, the same standard solutions of velpatasvir and sofosbuvir were injected 6 times into the HPLC system on the same day. The percentage RSD values calculated for peak areas of velpatasvir and sofosbuvir were less than $0.2 \%$ (Table-3) indicating the precise assay with the developed HPLC method. For accuracy, the percentage recovery was calculated for both active ingredients. The results (Table-3) are acceptable with good percent recovery.

Table-3: Precision and Accuracy Evaluation for the Developed Method

\begin{tabular}{c|c|c|c|c}
\hline \multirow{2}{*}{$\begin{array}{c}\text { Injection } \\
\text { Name. }\end{array}$} & \multicolumn{2}{|c|}{ Velpatasvir $(40 \mu \mathrm{g} / \mathrm{mL})$} & \multicolumn{2}{c}{ Sofosbuvir $(80 \mu \mathrm{g} / \mathrm{mL})$} \\
\cline { 2 - 5 } & Area of peak & Recover $\%$ & Area of peak & Recover $\%$ \\
\hline A & 2432746 & 99.35 & 5953930 & 99.72 \\
\hline B & 2438324 & 99.58 & 5954860 & 99.73 \\
\hline C & 2438753 & 99.6 & 5957679 & 99.78 \\
\hline D & 2431867 & 99.31 & 5956388 & 99.76 \\
\hline E & 2433053 & 99.36 & 5956731 & 99.77 \\
\hline F & 2438217 & 99.57 & 5955089 & 99.74 \\
\hline Mean & 2436043 & 99.48 & 5956149 & 99.76 \\
\hline RSD & 0.136 & 0.138 & 0.020 & 0.201 \\
\hline
\end{tabular}

\section{Recovery Test}

Further evaluation of the accuracy of the method was carried through recovery test. Recovery test was determined by means of the standard addition method. The recovery experiments were performed by adding velpatasvir and sofosbuvir standards at three concentration levels to the placebo for three times. The recovery test results are summarized in Table 4. Hence, the obtained results indicated that the developed HPLC method was accurate enough for simultaneous quantitative evaluation of aspirin and pravastatin. There was no interference noticed from the common excipients of the tablet.

Table-4: Recovery of Velpatasvir and Sofosbuvir by the Developed Method

\begin{tabular}{|c|c|c|c|c|c|c|c|}
\hline \multicolumn{2}{|c|}{$\begin{array}{l}\text { Concentration } \\
(\mu \mathrm{g} / \mathrm{mL})\end{array}$} & \multirow[t]{2}{*}{ Recover \% } & \multirow[t]{2}{*}{ Average $\%$} & \multicolumn{2}{|c|}{$\begin{array}{l}\text { Concentration } \\
(\mu \mathrm{g} / \mathrm{mL})\end{array}$} & \multirow[t]{2}{*}{ Recover \% } & \multirow{2}{*}{$\begin{array}{c}\text { Average } \\
\%\end{array}$} \\
\hline added & found & & & added & found & & \\
\hline \multicolumn{4}{|c|}{ Velpatasvir } & \multicolumn{4}{|c|}{ Sofosbuvir } \\
\hline 9.90 & 9.95 & 100.48 & \multirow{3}{*}{100.40} & 40.00 & 39.92 & 99.81 & \multirow{3}{*}{99.63} \\
\hline 9.90 & 9.96 & 100.65 & & 40.00 & 39.80 & 99.50 & \\
\hline 9.90 & 9.91 & 100.06 & & 40.00 & 39.83 & 99.58 & \\
\hline 19.80 & 19.90 & 100.51 & \multirow{2}{*}{100.36} & 80.00 & 79.73 & 99.67 & \multirow{2}{*}{99.71} \\
\hline 19.80 & 19.85 & 100.25 & & 80.00 & 79.81 & 99.76 & \\
\hline
\end{tabular}


RASĀYAN J. Chem.

Vol. 11 | No. 3 |1058 - 1066 | July - September | 2018

\begin{tabular}{|c|c|c|c|c|c|c|c|}
\hline 19.80 & 19.86 & 100.30 & & 80.00 & 79.76 & 99.70 & \\
\hline 29.70 & 29.83 & 100.45 & \multirow{3}{*}{100.47} & 120.00 & 119.61 & 99.68 & \multirow{3}{*}{99.68} \\
\hline 29.70 & 29.87 & 100.58 & & 120.00 & 119.64 & 99.70 & \\
\hline 29.70 & 29.81 & 100.38 & & 120.00 & 119.60 & 99.67 & \\
\hline
\end{tabular}

\section{Robustness}

Under the slightly varied chromatographic conditions (mobile phase's flow rate $- \pm 0.1 \mathrm{~mL} / \mathrm{min} \&$ temperature in the column $- \pm 2{ }^{\circ} \mathrm{C}$ ), velpatasvir and sofosbuvir peaks were well separated and there was no significant change in the system suitability parameters (Table-5), which illustrated the robustness of the method.

Table-5: System Suitability Values for Velpatasvir and Sofosbuvir under Slightly Varied Chromatographic Conditions

\begin{tabular}{c|c|c|c|c}
\hline \multirow{2}{*}{ Investigated factors } & Values & Plate Count & $\begin{array}{c}\text { Tailing in } \\
\text { peak }\end{array}$ & Resolution \\
\hline \multirow{5}{*}{ Velpatasvir $(40 \mu \mathrm{g} / \mathrm{mL})$} \\
\hline \multirow{2}{*}{ Flow rate $(\mathrm{mL} / \mathrm{min})$} & $1.0-0.1$ & 21895 & 1.14 & - \\
\cline { 2 - 5 } & $1.0+0.1$ & 19510 & 1.16 & - \\
\hline \multirow{2}{*}{ Temperature $\left({ }^{\circ} \mathrm{C}\right)$} & $25-2$ & 20992 & 1.18 & - \\
\cline { 2 - 5 } & $25+2$ & 20742 & 1.16 & - \\
\hline \multicolumn{5}{|c|}{ Sofosbuvir $(80 \mu \mathrm{g} / \mathrm{mL})$} \\
\hline \multirow{2}{*}{ Flow rate $(\mathrm{mL} / \mathrm{min})$} & $1.0-0.1$ & 17480 & 1.20 & 9.23 \\
\cline { 2 - 5 } & $1.0+0.1$ & 15889 & 1.19 & 8.92 \\
\hline \multirow{2}{*}{ Temperature $\left({ }^{\circ} \mathrm{C}\right)$} & $25-2$ & 16511 & 1.20 & 8.91 \\
\cline { 2 - 5 } & $25+2$ & 16891 & 1.20 & 9.06 \\
\hline
\end{tabular}

\section{Degradation Studies}

Solutions of velpatasvir and sofosbuvir tablet are stressed under acidic, oxidative, alkali, thermal \& photolytic conditions. Method's ability of stability indication and specificity are tested pertaining to the above-said conditions. Results of degradation studies are provided in Table-6. Degraded sample's chromatograms shown in Fig. -5 . The degradation percentage was estimated from the peak area obtained in degradation conditions and it was compared with the assay of the nondegraded condition.

Both the drugs were degraded in all the stress conditions applied. In the entire degradation conditions, one degradant peak is observed. From the results, it was observed that the velpatasvir is degraded more in thermal \& less in oxidative degradations. Sofosbuvir degradation is more in acid condition but less in thermal degradation. The peak purity profile of velpatasvir and sofosbuvir was determined. The less value of purity angle than purity threshold value showed that velpatasvir \& sofosbuvir peaks are homogeneous in every condition of degradation. Method's nature of stability indication \& specificity is demonstrated because degradation products of applied stress have no any effect on the detection and quantitation of velpatasvir and sofosbuvir.

\section{Comparison of the Proposed Method with Reported Methods}

Two HPLC methods are done on simultaneous evaluation of velpatasvir \& sofosbuvir in tablet forms ${ }^{8,9}$. Performance of reported and proposed HPLC methods is summarized in Table-7. From the values in the Table-7, it was observed that the proposed method have advantages of being more quick, precise \& accurate than the reported HPLC methods. The less runtime in the proposed method not only reduces the single analysis time but also decreases the utilization of solvents. Thus the proposed method is economical than the reported HPLC methods. Both the reported methods were not fully validated. The LOD and LOQ are not presented in the Sarath \& $\mathrm{Rao}^{6}$ method. The specificity and selectivity are not reported in Uppalapati \& Parimi ${ }^{7}$ method. 
RASĀYAN J. Chem.

Vol. 11 | No. 3 |1058 - 1066 | July - September | 2018
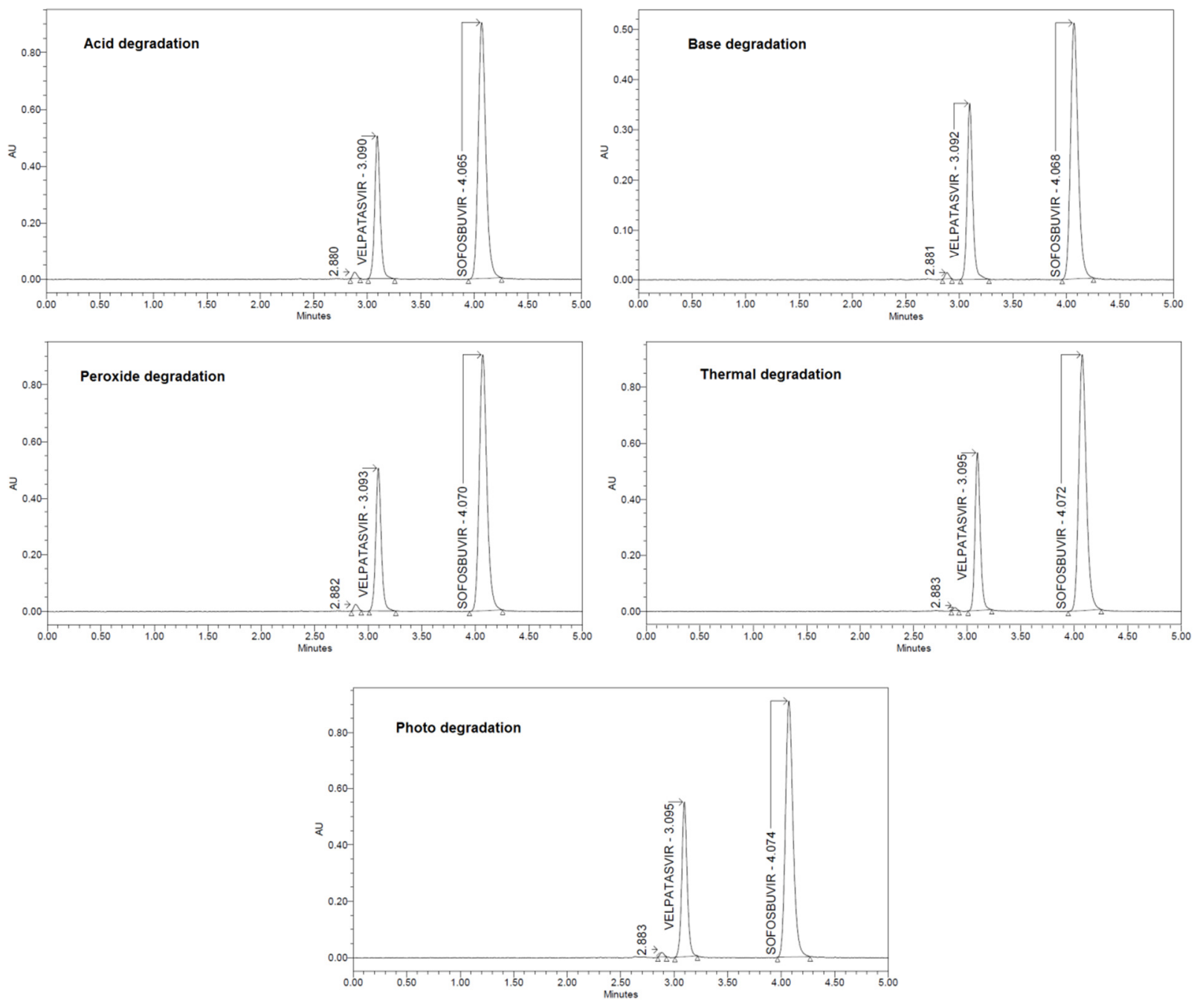

Fig.- 4: Chromatograms of stress testing

Table-6: Stress Testing of Velpatasvir and Sofosbuvir

\begin{tabular}{|c|c|c|c|c|c|}
\hline \multirow[b]{2}{*}{ Degrading type } & \multirow[b]{2}{*}{ Area of peak } & \multirow{2}{*}{$\begin{array}{c}\text { Recover } \\
\%\end{array}$} & \multirow{2}{*}{ Degraded \% } & \multicolumn{2}{|c|}{ Purity } \\
\hline & & & & Angle & Threshold \\
\hline \multicolumn{6}{|c|}{ Velpatasvir $(40 \mu \mathrm{g} / \mathrm{mL})$} \\
\hline Acid & 2282112 & 93.20 & 6.80 & 0.420 & 0.908 \\
\hline Base & 2297127 & 93.81 & 6.19 & 0.321 & 0.826 \\
\hline Oxidative & 2304684 & 94.12 & 5.88 & 0.283 & 0.892 \\
\hline Heat & 2272016 & 92.79 & 7.21 & 0.377 & 0.912 \\
\hline Sunlight & 2295250 & 93.73 & 6.27 & 0.386 & 0.924 \\
\hline \multicolumn{6}{|c|}{ Sofosbuvir $(80 \mu \mathrm{g} / \mathrm{mL})$} \\
\hline Acid & 5526135 & 92.55 & 7.45 & 0.354 & 0.525 \\
\hline Base & 5543131 & 92.84 & 7.16 & 0.231 & 0.425 \\
\hline Oxidative & 5529439 & 92.61 & 7.39 & 0.323 & 0.528 \\
\hline Heat & 5585557 & 93.55 & 6.45 & 0.205 & 0.432 \\
\hline Sunlight & 5568801 & 93.27 & 6.73 & 0.299 & 0.443 \\
\hline
\end{tabular}

CONCLUSION

In this study, an RP-HPLC method which is stability indicating was optimized and validated for determining velpatasvir \& sofosbuvir in raw and tablets. The method was rapid, cost-effective, accurate $\&$ 


\section{RASĀYAN J. Chem.}

Vol. 11 | No. 3 |1058 - 1066 | July - September | 2018

precise with good selectivity and specificity. Results of this method validation showed that the method was satisfactory and so this method can be applicable in regular quality control laboratories.

Table-7: Comparison of the Proposed Method with Reported HPLC Method

\begin{tabular}{|c|c|c|c|c|c|c|c|c|}
\hline Drug & $\begin{array}{l}\text { Run } \\
\text { time } \\
\text { (min) }\end{array}$ & $\begin{array}{l}\text { Flow rate } \\
(\mathrm{mL} / \mathrm{min})\end{array}$ & $\begin{array}{l}\text { Range } \\
\mu \mathrm{g} / \mathrm{mL}\end{array}$ & $\begin{array}{c}\mathrm{LoD} \\
\mu \mathrm{g} / \mathrm{mL}\end{array}$ & $\begin{array}{c}\mathrm{LoQ} \\
\mu \mathrm{g} / \mathrm{mL}\end{array}$ & $\begin{array}{c}\mathrm{RSD} \\
\%\end{array}$ & Recover \% & Reference \\
\hline Vel & \multirow{2}{*}{6} & \multirow{2}{*}{1.0} & $\begin{array}{l}25.293- \\
252.928 \\
\end{array}$ & NR & NR & $\begin{array}{c}0.13- \\
0.55 \\
\end{array}$ & $\begin{array}{l}99.98- \\
100.64 \\
\end{array}$ & \multirow{2}{*}{$\begin{array}{c}\text { Sarath \& } \\
\text { Rao [8] }\end{array}$} \\
\hline Sof & & & $\begin{array}{l}100.339- \\
1003.391 \\
\end{array}$ & NR & NR & $\begin{array}{c}0.37- \\
0.98 \\
\end{array}$ & $\begin{array}{l}98.96- \\
100.15 \\
\end{array}$ & \\
\hline Vel & \multirow{2}{*}{8} & \multirow{2}{*}{1.0} & $20-60$ & 0.001 & 0.003 & 0.42 & $\begin{array}{l}98.80- \\
100.50 \\
\end{array}$ & \multirow{2}{*}{$\begin{array}{l}\text { Uppalapati } \\
\text { \& Parimi }[9]\end{array}$} \\
\hline Sof & & & $80-240$ & 0.005 & 0.02 & 0.25 & $\begin{array}{l}99.30- \\
100.50\end{array}$ & \\
\hline Vel & \multirow{2}{*}{5} & \multirow{2}{*}{1.0} & $10-30$ & 0.186 & 0.620 & $\begin{array}{c}0.136- \\
0.138 \\
\end{array}$ & $\begin{array}{c}100.36- \\
100.47\end{array}$ & \multirow{2}{*}{$\begin{array}{l}\text { Proposed } \\
\text { method }\end{array}$} \\
\hline Sof & & & $40-120$ & 0.482 & 1.609 & $\begin{array}{c}0.020- \\
0.021\end{array}$ & $\begin{array}{l}99.63- \\
99.71\end{array}$ & \\
\hline
\end{tabular}

Vel - velpatasvir; Sof - sofosbuvir; NR - not reported.

\section{ACKNOWLEDGMENT}

Authors thank M/s Lara Drug Private Limited, Hyderabad (Telangana, India) for providing gift samples, sofosbuvir and velpatasvir and also to CMR college of Pharmacy, Medchal for permitting to avail the facilities for research work.

\section{REFERENCES}

1. J.P. Messina, I. Humphreys, A. Flaxman, A. Brown, G.S. Cooke, O.G. Pybus and E. Barnes, Hepatology, 61(1), 77 (2015), DOI:10.1002/hep.27259.

2. J. S. Rani and N. Devanna, Rasayan J. Chem., 11(2), 452 (2018), DOI: 10.7324/RJC.2018.1122079.

3. C.W. Tseng, T.T. Chang, S.J. Tzeng, Y.H. Hsieh, T.H. Hung, H.T. Huang, S.F. Wu and K.C. Tseng, Clin. Interv. Aging, 11, 327, (2016), DOI: 10.2147/CIA.S97242.

4. https://www.fda.gov/newsevents/newsroom/pressannouncements/ucm508915.htm

5. J. Mamatha and N. Devanna, Rasayan J. Chem., 11(1), 392 (2018), DOI: 0.7324/RJC.2018.1111931.

6. Asselah T, Expert Opin. Pharmacother., 15(1), 121, (2014), DOI: 10.1517/14656566.2014.857656.

7. E. Mogalian, P. German, B.P. Kearney, C.Y. Yang, D. Brainard, J. Link, J. McNally, L. Han, J. Ling and A. Mathias, Antimicrob. Agents. Chemother., 61(5), e02084-16, (2017), DOI: 10.1128/AAC.02084-16.

8. N. Sarath and J.V.L.N.S. Rao, World J. Pharm. Pharma. Sci., 6(9),1596(2017), DOI: 10.20959/wjpps20179-10099.

9. J. Uppalapati and U. Parimi, Indo American J. Pharma. Res., 7(8), 401 (2017).

10. Q1A (R2) International Conference on Harmonization (ICH) of technical requirements for the registration of pharmaceutical for human use stability testing of new drugs substance and products, (2003).

11. ICH Validation of analytical procedures; Text and methodology; Q2(R1), International Conference on Harmonization, (2005).

[RJC-2010/2018] 